Article

\title{
When a Right-Wing Populist Party Inherits a Mass Party Organisation: The Case of EKRE
}

\author{
Tõnis Saarts *, Mari-Liis Jakobson and Leif Kalev \\ School of Governance, Law and Society, Tallinn University, Estonia; E-Mails: tonis.saarts@tlu.ee (T.S.), \\ mari-liis.jakobson@tlu.ee (M.-L.J.), leif.kalev@tlu.ee (L.K.) \\ * Corresponding author
}

Submitted: 29 May 2021 | Accepted: 8 October 2021 | Published: 24 November 2021

\begin{abstract}
When the Eesti Konservatiivne Rahvaerakond (EKRE, Estonian Conservative People's Party) took over the defunct but extensive party organisation of the Estonian People's Union, it placed great emphasis on rebooting and extending the organisation and bringing in new activists. As a result, EKRE has grown into a full-fledged mass party type of organisation with all the characteristics associated to it. Furthermore, it has become the fastest-growing party in Estonia in terms of membership and been notably successful in electoral terms. This article focuses primarily on the question of how EKRE developed a mass party organisation with a strong, ideologically-devoted activist core and a remarkable presence on the ground. The article also demonstrates how the party offers a variety of opportunities for engagement to its members. In contrast to an archetypical right-wing populist party, the decision-making power is somewhat diffused within the party, though the party leader remains the public face and mouthpiece of the party. EKRE's online engagement strategies have been among the most successful in recent Estonian politics and make the party stand out. The article demonstrates that parties can often revise as well as repurpose the features of the predecessor parties and even build defunct mainstream parties into mass parties with a firm ideological core.
\end{abstract}

\section{Keywords}

EKRE; Estonia; party organisation; right-wing populism; successor parties

\section{Issue}

This article is part of the issue "Right-Wing Populist Party Organisation Across Europe: The Survival of the Mass-Party?" edited by Daniele Albertazzi (University of Surrey, UK) and Stijn van Kessel (Queen Mary University of London, UK).

(C) 2021 by the authors; licensee Cogitatio (Lisbon, Portugal). This article is licensed under a Creative Commons Attribution 4.0 International License (CC BY).

\section{Introduction}

In spring 2012, the Eestimaa Rahvaliit (ERL, Estonian People's Union) - a by then defunct, but formerly major party-and a minor radical right activist group, the Eesti Rahvuslik Liikumine (ENM, Estonian Nationalist Movement), announced a merger and the creation of a new party: the Eesti Konservatiivne Rahvaerakond (EKRE, Estonian Conservative People's Party). In legal terms it was simply a name change and not recognised as a true merger (because one was a party and the other a small movement). However, it became an alliance in which the activists and ideological architects came from the ENM, and organisational structure and mass membership was inherited from the ERL. Political observers were initially sceptical whether the combination of a rather marginal (ENM) and a waning (ERL) political actor could achieve electoral success. However, the combination proved to be notably successful. In its first national election in 2015, EKRE won $8 \%$ of the seats in parliament. In the next election, in 2019, EKRE obtained $18 \%$ of the seats in the legislature and was invited to join a governing coalition (Mölder, 2020).

According to Arter (2012, p. 109), a successor party is born when a new party emerges after its predecessor ceases to exist and the replacement party becomes 
virtually a new political entity with a new name, changed ideology, and renewed electoral appeal, which enables it to fill and expand the remaining political niche. Most importantly, the successor party inherits the human, organisational, and financial resources from its predecessor, but seeks to develop them as a "new enterprise." EKRE fulfils all the criteria: It replaced ERL when the latter became dysfunctional, radically redefined the party's ideology, partly transformed the electoral base, and further developed the inherited party organisation on new grounds. Successor parties are rather common among populist radical right parties (PRRPs). For instance, the Freiheitliche Partie Österreichs (FPÖ, Austrian Freedom Party) formed based on the Verband der Unabhängigen ( $\mathrm{VdU}$, League of Independents) and the Perussuomalainen Puolue (PS, True Finns Party) replaced the Suomen Maaseudun Puolue (SPM, Finnish Rural Party), to name a couple (Arter, 2012). However, the organisational transformations of successor parties have not been studied widely.

This article aims to analyse how the succession process influenced the development of EKRE's mass party structure. As the introduction to this thematic issue states, the mass party model has proven to be popular and viable among a number of parties whose "populist message challenges 'the political elites' precisely for disengaging with ordinary citizens" (Albertazzi \& van Kessel, 2021 , p. 224). This article thus demonstrates a special case of mass party organisation-building among PRRPs in Central and Eastern Europe, showing that the relevant organisational model can also be found in the Eastern part of the continent. Furthermore, EKRE's case is interesting because it shows the development of a mass party structure in a successor party that partly draws from a grassroots activist group.

This article is focused on EKRE's party organisation and seeks answers to two principal research questions: To what extent and how has EKRE made an effort to develop a mass party type organisation? To what extent is EKRE centralised in terms of key decision-making areas?

The article will demonstrate that EKRE has developed an extensive party organisation reminiscent of a mass party. Even if the inherited party organisation proved to be a useful foundation for a mass party, the party leaders had to reboot the whole organisation. They reinvented the party's political programme, brought in new activists, and created new engagement strategies and institutional practices in order to create a fully functional organisation. Overall, EKRE has successfully adopted the mass party organisational model, and it is now the fastest-growing party in Estonia. Furthermore, it has also become a pioneer in online engagement strategies, having a notably larger online presence than other parties in Estonia. Regardless of its leader-centred public face, the party has developed relatively advanced mechanisms for intra-party democracy. The party has multiple institutionalised and non-institutionalised avenues for engaging local elites, members, and supporters into the decision-making process, even if there is only anecdotal evidence of the grassroots affecting the party's policy.

The study relies primarily on secondary source analysis (party charters, party membership lists, electoral data, speeches and press releases, media texts, online archives, social media pages), but also draws on 12 qualitative interviews conducted with members of EKRE who hold, or have held, positions in the party's decisionmaking bodies or in branch- or district-level leadership. The interviewees were drawn from a diverse spectrum of activists who varied in terms of their age, gender, and period of party membership (see Supplementary File).

\section{The Origins and Development of EKRE}

EKRE is often classified as a PRRP (Mudde 2016, p. 7; see also Braghiroli \& Petsinis, 2019; Kasekamp et al., 2019; Petsinis, 2019) although, as our interviews indicate, the members prefer to see themselves as "national conservatives." Its ideology is based on nativism (an anti-Russian stance and anti-immigration sentiments), Euroscepticism, and the promotion of traditional family values. One can also add anti-liberal views (limits on individual freedom and an emphasis on collective national values) and elements of populism such as anti-elite rhetoric and an appeal to "the people" (Braghiroli \& Petsinis, 2019; Kasekamp et al., 2019).

The ENM, which joined ERL in forming EKRE, was a relatively small nationalistic and Eurosceptic group (Braghiroli \& Petsinis, 2019) with around 300 members (Kund, 2012). In contrast, the socially conservative and agrarian ERL had been one of the mainstream parties in Estonia, whose membership peaked at around 10,000 in its heyday (Toomla, 2011). ERL was founded in 2000, when two smaller agrarian parties and a retirees' party merged. Its predecessors date back to the rural participants of the late Soviet time pro-independence movements and the 1990s countermovement against rural decline and neoliberal reforms. As a merger party, ERL was initially quite diverse, but consolidated under the broad umbrella of an agrarian-conservative ideology with a solidaristic and mild nationalist leaning.

ERL participated in several governments and developed a well-oiled patronage network that facilitated the consolidation of its elites. This resulted in a spiral of decline after 2006 when the party faced corruption charges. In the 2007 elections, ERL lost more than half of its seats (from 13 to six) and moved into opposition (Saarts, 2015). Subsequently, the party lost almost all support it had, and many prominent members joined other parties' ranks. There was a failed attempt to merge with the Sotsiaaldemokraatlik Erakond (SDE, Social Democratic Party of Estonia), which caused further tensions within the top echelons of the party and resulted in the younger and more progressive elites leaving ERL. By the time ERL merged with the ENM, the party mainly consisted of the elderly agrarian elite with 
broadly nationalist and social conservative orientations and a declining and passive membership.

Even in this situation, ERL provided the main organisational foundations for the new party. It provided the first chairman of EKRE (Margo Miljand) who served for a year before EKRE's long-term leader Mart Helme (2013-2020) took over. By that time, Mart Helme was already a well-known public personality in Estonia. He had served as an ambassador in Russia in the 1990s and had later become one of the figureheads of the nascent Eurosceptic conservative movement in Estonia, known for his radical public statements (see Auers \& Kasekamp, 2015). Mart Helme served as a charismatic leader and figurehead of the party, but the party has rarely been seen as his personal vehicle. In addition to Mart Helme, several other people have become highly visible and important spokespersons of the party, among them other members of the Helme family: his son Martin Helme, who assumed party leadership in 2020, and his wife Helle-Moonika Helme, who has also been part of the party leadership. While Helle-Moonika Helme was a newcomer in politics when joining the party in 2012, Martin Helme had already built a solid public profile as a radical and Eurosceptic activist.

One should also not underestimate the role played by the former Estonian president Arnold Rüütel, who had served as a prominent member of ERL and later became the honorary chairman of the EKRE. As he was still very popular among the rural population, he contributed to legitimising EKRE as a successor party of ERL (Auers \& Kasekamp, 2015, p. 145).

EKRE inherited a strong and geographically extensive party organisation from ERL, with ca. 8,000 members (Toomla, 2011). Thus, EKRE had a mass party type of organisation already from the outset. However, while ERL relied on its patronage networks and almost constant presence in government (Saarts, 2015), EKRE significantly strengthened the emphasis on ideology.

Few commentators (see, e.g., Auers \& Kasekamp, 2013) saw potential in EKRE at that time, as many parties had already adopted an ethnonationalist agenda and the $5 \%$ national electoral threshold is rather high for newcomers. The window of opportunity opened for EKRE when Estonia adopted the Civil Partnership Act, which legalised gender neutral partnerships in 2014 (Kasekamp et al., 2019). That was a wake-up call for the more socially conservative segment of society, which lacked prominent spokespersons in parliamentary politics at the time. EKRE and the Helme family were able to fill the void. In the subsequent national elections, in March 2015, the party obtained $8 \%$ of votes and $7 \%$ of seats in the parliament (Table 1).

The European refugee crisis of 2015-2016 further increased the popularity of the party. By utilising the antiimmigration card and anti-establishment rhetoric, EKRE was able to obtain $18 \%$ of the vote in the national elections in 2019. The electoral success was further boosted by the personal charisma of the then chairman Mart Helme and systematic campaigning and organisationbuilding efforts (largely in the less affluent rural districts).

After the 2019 election, EKRE entered government. The former incumbent party, Eesti Keskerakond (KE, Estonian Centre Party) unexpectedly lost the elections, but, in order to remain in power, and since it had few options on the table, decided to cooperate with EKRE (Mölder, 2020). In government, EKRE did not manage to implement the more radical parts of its agenda (Jakobson \& Kalev, 2020). However, it was rather successful in utilising government media briefings to maintain public attention on their policy positions. Hoping to expand its appeal to new electoral segments, EKRE elected a new chairman (Martin Helme) in 2020.

\section{The Efforts to Build and Maintain a Mass Party Type of Organisation}

According to Panebianco (1988) and Albertazzi (2016), a mass party type of organisation is characterised by the drive to recruit a large activist membership as a way to reach out to the public, rootedness to the ground, a well-articulated ideology creating a distinct collective identity, and sense of community (see also Albertazzi \& van Kessel, 2021). While EKRE's leadership noted that "establishing a mass party type of structure was never a goal on its own" (Interview 10), EKRE can be said to meet all these criteria. While it builds on ERL's heritage in terms of its structure and extent of party organisation, it has developed even further towards a mass party structure.

While ERL was rather pragmatic and technocratic (Saarts, 2015), EKRE describes itself as "the most ideological party in Estonia” (Helme, 2020). EKRE has a rather

Table 1. Performance of EKRE and its predecessors in the national elections.

\begin{tabular}{llllllll}
\hline Year & 1995 & 1999 & 2003 & 2007 & 2011 & 2015 & 2019 \\
\hline Party & Electoral alliance KMÜ & EME (ERL) & ERL & ERL & ERL & EKRE & EKRE \\
Seats & $41\left(23^{*}\right)$ & $7\left(11^{*}\right)$ & 13 & 6 & 0 & 7 & 19 \\
Votes & 174,248 & 35,204 & 64,643 & 39,215 & 12,184 & 46,772 & 99,671 \\
Vote share & 32,2 & 7,3 & 13,0 & 7,1 & 2,1 & 8,1 & 17,8 \\
\hline
\end{tabular}

Notes: The first number is the result of the formal electoral list, the latter stands for the actual number of deputies of the ERL; KMÜ: Koonderakond ja Maarahva Ühendus (The Coalition Party and Estonian Country People's Party Union); EME: Eesti Maarahva Erakond (Estonian Country People's Party). Source: Estonian National Electoral Committee (2021). 
broad societal following and has been associated with a wider nativist conservative movement, which has been on the rise both internationally as well as in Estonian society since the mid-2010s (Kasekamp et al., 2019). ERL was never supported by such a wider social movement, although its predecessors were (the rural movement in the 1990s).

After the merger, the new activists predominantly came from the ENM's side or from the newly recruited members. Even if, immediately after the merger, some former members of the ERL were still playing a relatively active role in organisational affairs and central leadership, the newly recruited members and ENM's activists "soon took the lead" (Interview 10).

Currently, EKRE is the third largest, but also the fastest-growing party in Estonia: While the membership of the other parties has stagnated or increased at a low pace, the membership of EKRE (along with the Estonian Centre Party) has grown considerably (Estonian e-Business Register, 2021). Between 2015 and 2020, EKRE recruited 3033 new members and most of this growth happened naturally, without major recruitment campaigns. To date (2021), the party has launched only two centralised recruitment campaigns. The 2015-2016 campaign, during the refugee crisis, was not very successful. However, in 2021, when the party fell out of the governing coalition, the leadership was more successful in sustaining momentum and gained hundreds of new members.

It is equally noteworthy that, so far, EKRE has been the only Estonian party to have established a party organisation abroad (see Jakobson et al., 2020). In 2013, conservative-minded Estonians living in Finland founded EKRE's party branch there, and in 2019 another external branch organisation was founded in Sweden. It was a genuine bottom-up initiative, which also refers to ideologically motivated grassroots activism rather reminiscent of a mass party.

Unlike some other PRRPs (see, e.g., Albertazzi, 2016) and many other parties in Estonia, the party only has full members and no supporting members, whose association to the party is not made public. Also, the process of accepting new members is more rigorous than it was in the ERL. New members go through background checks-a measure that was implemented in order to keep away "troublemakers" and avoid scandals over members who have committed felonies (Interviews 1, 4). Nonetheless, the party has still witnessed some public scandals around wayward members. Most notably, one of the party's candidates for minister in the cabinet formed in spring 2019 was caught driving under the influence of alcohol and was later accused of domestic violence. The party was forced to withdraw his candidacy ("Kuusik accused," 2019).

Additionally, applicants for party membership can also name an endorser among party members to boost their applications. The application procedure thus expects active agency and some networking on behalf of the applicants and is not designed merely for maximising the number of formal members.

Among EKRE's members one can find both the new members and those who had formerly joined with the predecessor parties. As of January 2021 (see Figure 1), over half of EKRE's members had joined the party before the 2012 rebranding-most prominently into ERL, but some do remain members since the 1990 s, i.e., from earlier periods of party succession. It is even likely that many people who were members of the predecessor parties

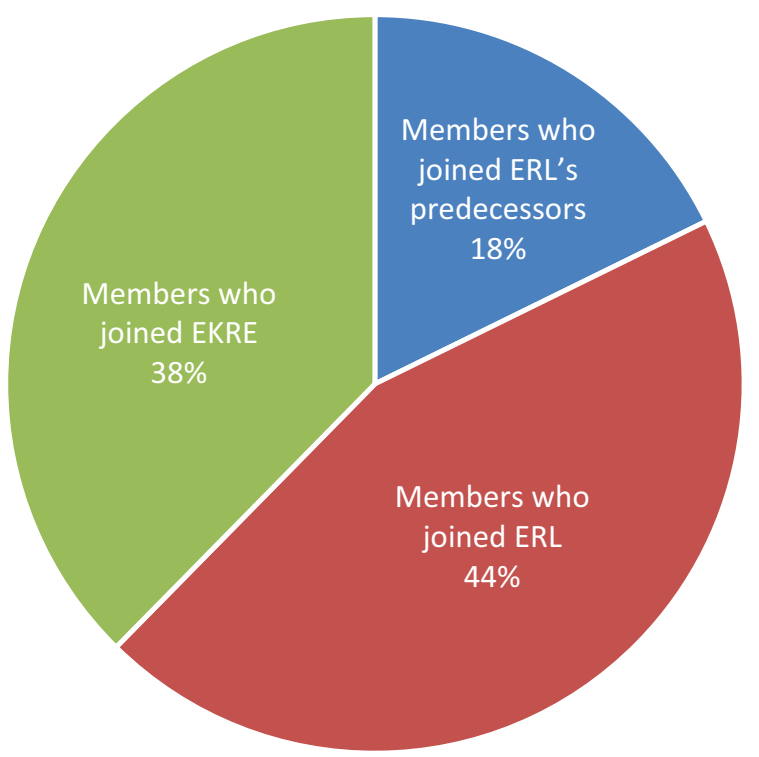

Figure 1. EKRE's members on 1 January 2021, according to the time and legal entity they joined. Time periods for calculating the number of members we as follows: Members who joined ERL's predecessors (25 January 1990-6 June 2000), ERL (10 June 2000-23 March 2012), and EKRE (24 March 2012-31 December 2020). Source: Estonian e-Business Register (2021). 
have not been made fully aware that they are members of EKRE, since inherited members have not been required to renew their membership or pay membership fees.

EKRE has built its territorial organisation largely upon the nation-wide network developed by ERL, but the party has made a considerable effort to re-activate and expand the local organisations-for instance, in his inauguration speech, the new party chairman Martin Helme emphasised the need to have a branch organisation in every single municipality by 2021 (Helme, 2020). In contrast to its predecessor, EKRE has also achieved a solid presence in larger cities. While ERL tried to penetrate the cities (e.g., the capital city Tallinn), it never succeeded, and the party even failed to field a full list of candidates there (Saarts, 2015). By contrast, EKRE has founded vibrant branches in all electoral districts of Tallinn. In the 2017 local elections, the party compiled the third-longest list of candidates for local elections in Tallinn and even got six representatives into the city council.

Regarding the party structure, EKRE initially adopted virtually all the organisational principles of ERL, but altered them somewhat afterward. Like all Estonian parties, EKRE's organisational structure consists of three levels: the local branch, the district, and central level. A branch organisation is formed on the basis of local election districts and needs at least five members to be formally founded. Branch organisations have a directly elected leadership consisting of a chair, vice-chairs, and a local leadership board (Party Charter of EKRE, 2016).

However, while EKRE initially adopted ERL's organisational model where districts overlapped with counties (Party Charter of EKRE, 2012), the structure was soon altered to a more functional model where party districts follow the lines used in national elections-leaving aside its foreign branches (Jakobson et al., 2020).

As with all Estonian parties, the highest decisionmaking body is the party congress-consisting of all members who typically meet once a year. In the meantime, decisions are taken by the board of trustees, which convenes monthly and consists of the chairmen of the districts (plus an extra member for every additional 300 members), 15 directly elected representatives, all the party MPs, group representatives, honorary chairs, and the central leadership of the party. In late 2020, the board of trustees consisted of 87 members, the majority of whom are representatives of districts.

Executive power is vested in the party leadership, which consists of the party chair and three vice-chairs. They are assisted by the party's leadership board, which is directly elected at the party congress and currently consists of 11 members.

As a proper mass party, EKRE has also established a wide array of intra-party groups and affiliated organisations, which attempt to strengthen the ideological devotion of the members. For instance, the party has an active youth organisation, a women's group, and a choir. Organisational activities are further supplemented with local-level discussion clubs, regular festive events, and extensive online engagement platforms.

While the statutory rules regarding the formation and internal organisation of intra-party groups have been copied from ERL, the regulatory shell has been filled with "notably more ideological content" (Interview 11). For instance, the youth organisation, Blue Awakening (Sinine Äratus), plays an important ideological role by organising the annual Etnofutur conference, which welcomes identitarian and far right activists across the world as speakers, and organising the party's annual torch march on Estonian Independence Day, which usually attracts over a couple of thousand participants and involves political speeches by the party leaders. The aesthetics of the torch marches bear resemblance to the contemporary torch marches of various radical and far right groups in other countries, which have been linked to the historical torch marches in Nazi Germany and those in the US by the Ku Klux Klan (Korhonen, 2020). However, there has also been a long-lived tradition in the region in which student sororities organize their own torch processions. In case of EKRE the event also feeds into the sense of community among party members and gives an impression to the general public that the party is backed up by a broader popular movement (Interviews 5, 10).

The Blue Awakening is ideologically further to the right than the main party and openly associates with organisations such as the Swedish youth organisation Nordisk Ungdom, which have been characterised as Nazi and right-wing extremist. The organisation has also served as a breeding-ground for the new party elites. For instance, EKRE's representative in the European Parliament, Jaak Madison (belonging to the Identity and Democracy Group), has a background in the youth organisation.

The central and district levels also organise various discussion events-for instance, in late 2020, the party had a series of meetings between the party's headlining politicians and supporters titled "Dialogue With the People" (Kahekõne Rahvaga). Districts organise talks on various topics that "provoke people to think" (Interview 8), such as nationalism, democracy, humanism, etc. The party or its district organisations are also active in organising political rallies, e.g., in support of the Estonian language high school in the predominantly Russian-speaking town Kohtla-Järve, or commemoration ceremonies of the important events for Estonian independence and statehood.

The shift towards more profound ideological engagement has also been supported by the party's activities online. In 2015, party activists founded the "national conservative news and opinions portal" Uued Uudised (https://uueduudised.ee). It could be classified as politically alternative media (Kasekamp et al., 2019), but shows some features of hyperpartisan media. Stier et al. (2020, p. 431) define hyperpartisan media as sources that purport "to be news outlets while promoting a narrow and skewed political agenda without making 
an effort toward a balanced representation of major political issues, events or political actors." In the second half of 2020, Uued Uudised drew on average 41,125 unique visitors per week (Metrix Station, 2021, authors' calculations for 1 June 2020-3 January 2021), which is among the largest in the Estonian alternative media scene. In comparison, another well-known outlet, conspiratorialist-spiritual Telegram received on average 19,232 unique visitors per week over the same period. However, it still remains modest in comparison to larger news outlets. The most widely visited news portal Delfi received over 1,1 million unique browser visits per week (Gemius, 2021).

Uued Uudised provides an important component for EKRE's online presence, as it is the main reference source to EKRE's numerous social media channels. The party has a notable social media presence. In addition to the party's national Facebook page, most of its branch and district organisations have a Facebook page, often accompanied by a closed Facebook group "for coordinating activities with the more engaged activists" (Interview 6). One of the party's goals has been to reinforce the communication capacities of the regions (Espenberg, 2018). In addition, the party also has a closed Facebook group, the EKRE's Friends Club (EKRE Sõprade Klubi), which is a discussion board for people who are not necessarily members of the party, but align ideologically. The group was initiated in September 2014, i.e., when the Civil Partnership Act act emerged on the political agenda. At the end of 2020, the group had around 7500 members and a notably active membership with around 40 posts daily. At the time of writing, EKRE's online and social media presence exceeded other parties in Estonia (see Figure 2).

Another important communication tool for consolidating the party's support base and achieving a wider public resonance has been the weekly radio show Räägime Asjast (which broadly translates to "let's talk about the important thing") on a relatively small radio channel owned by a prominent member of the party, TRE Radio. The show features the Helmes' father-son duo analysing weekly political events. When EKRE was in government, the Helmes utterances during this show generated several scandals and controversies, some of which reached even the international arena. For instance, Mart Helme's characterization of the Finnish prime minister as a "sales girl" ("Estonian minister under fire," 2019) or questioning the legitimacy of Joe Biden's presidency in the US (O'Grady, 2020).

As demonstrated above, EKRE presents numerous clear characteristics of mass party organisation: a vibrant and growing membership, a significant activist core, an extensive party organisation, and strong impetus to ideology. While EKRE's leaders have never considered the development of an extensive mass party type of organisation as a priority on its own, it could be seen as a pure necessity and a pragmatic choice. First, a mass party type organisation has been a way to increase the party's public legitimacy. Many see EKRE as a fringe party with an extreme ideology, and so there has been an urgent need to demonstrate that the party has a much wider public support and could be considered a true "people's party." The "people's party" image is also extremely important considering the party's populist ideology. Second, party membership numbers are relatively high in Estonia (one of the highest in Central and Eastern Europe; see Biezen et al., 2012). Since the 2000s, there has been a constant competition between the Estonian parties over membership size. Thus, EKRE's leadership, whose ambition has been to become the largest party in Estonia and to obtain the prime ministership (Helme, 2020), could not afford to ignore that race

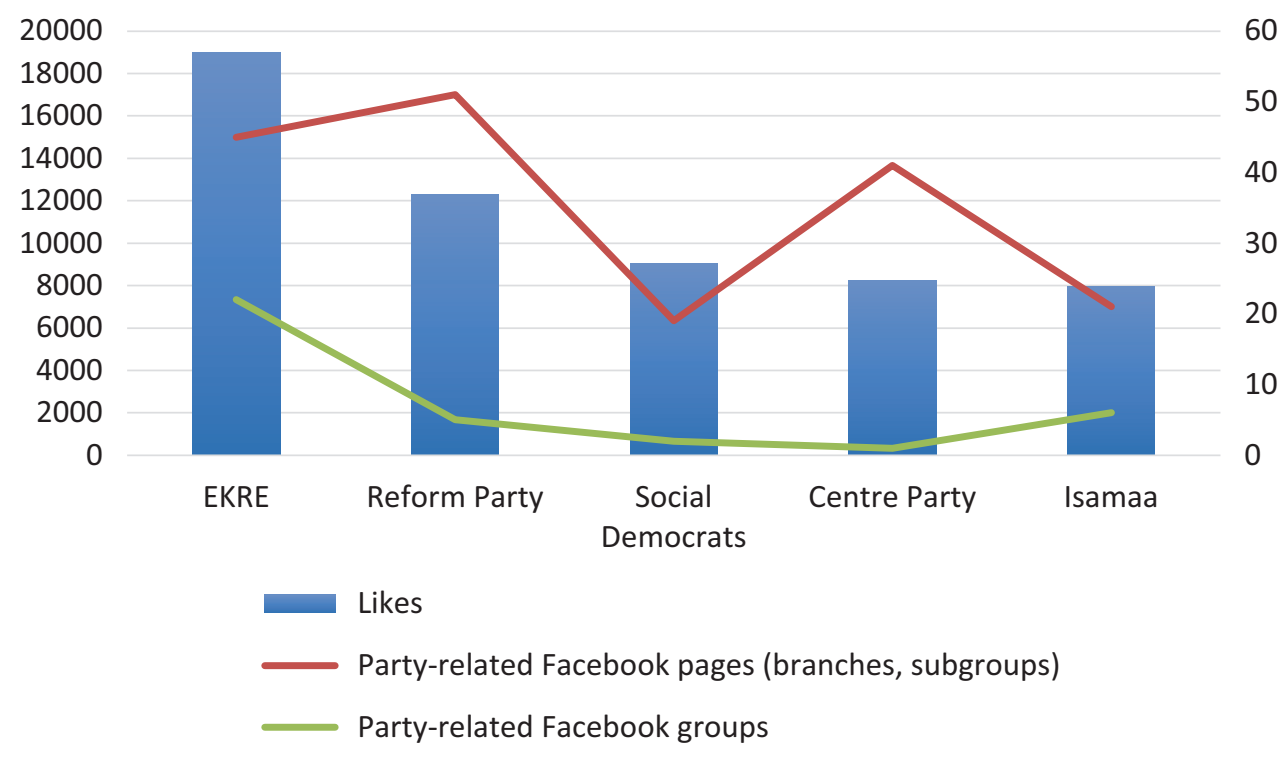

Figure 2. Parties' official Facebook page likes and number of party-related Facebook pages and groups on 12 March, 2021. 
and neglect organisation-building. Finally, one has to consider the party's history and the socio-demographic profile of its supporters. Lower-income groups are overrepresented in EKRE's support base: They are usually middle-aged and often live in rural districts and smaller towns (Trumm, 2018). Given these characteristics, the traditional "party on the ground" mobilisation strategies would work much better with them than a thin party organisation mostly visible and active online.

\section{Centralisation of Power and Internal Democracy in EKRE}

In many ways, EKRE's image corresponds to a typical populist party in terms of its leadership (see, e.g., Heinisch \& Mazzoleni, 2016). Following Eatwell's (2018) theory on the charismatic leadership of PRRPs, it appears that Mart Helme possesses many traits of a charismatic leader: radical mission, personal presence, closeness to the people (symbiotic hierarchy), and Manichean demonization of its opponents. During his time as party chairman, Mart Helme frequently appealed to the masses and gained media attention with colourful assertions. Furthermore, the hereditary element witnessed in some PRRPs (Heinisch \& Mazzoleni, 2016) is evident also in the case of EKRE, as the chairman position passed from father Mart Helme to son Martin Helme in an uncontested leadership election at a snap Party Congress in the summer of 2020. Previously Martin Helme was one of the 11 members of the party's leadership board (the positions of vice-chairmen were reserved for other prominent party members), but after the election, father Mart Helme became one of the three vice-chairmen. Furthermore, Mart Helme's wife Helle-Moonika Helme has been an important spokesperson for the party, a member of the party's leadership board, and vice-chairman of the party's parliamentary faction since 2021. The family-centred leadership model described earlier is unusual even among other PRRPs in the Baltic states (Wierenga, 2019).

The Helmes alone do not constitute the party's leadership as such, but play a major strategic role inside the party. The Helmes have adopted the journalistic derogatory "two-men-backroom" (consisting of Martin and Mart Helme) as a self-legitimating discourse: they acknowledge that the father-son-tandem works closely together and have framed their close cooperation as something highly beneficial to the party (Helme, 2020). The party also depicts the passing of the leadership position from father to son in a positive sense: namely, as a means to safeguard continuity.

Our interviews reveal that, unlike public performance, where leadership plays a very important role, the decision-making power within the party is more dispersed. While the Helmes still feature most prominently in public, there are also other actors in the party, who can influence the internal decision-making process. Consequently, there are different power-centres within the party beyond the "two-men-backroom": the directly elected vice-chairmen, the board of trustees, and the leadership board, in particular, have become the major nerve-centres of the party (Interviews 11, 12). Some of these venues are more institutionalised, while others can influence decisions more on an ad hoc basis. For instance, one of the interviewees described the ad hoc consultations in the leadership board: When Mart Helme's scandalous statements caused a media storm, chairperson Martin Helme discussed possible response strategies (Interview 8).

First, EKRE has developed a significant infrastructure for internal democracy. Unlike other Estonian parties which generally tend to re-elect the leadership every two or three years (Aylott, 2014), EKRE re-elects its representative and executive bodies annually. Besides the annually re-elected party chairman and vice-chairmen, the party also has an elected leadership board and a board of trustees, consisting of directly elected and locally assigned members, which issues regular political statements and is in charge of approving decisions between party congresses. However, the leadership board, in particular, is generally considered the major nerve-centre of the party and the body for everyday strategic decisionmaking (Interviews 10, 12).

Unlike the party chairman elections, which have thus far (2012-2020) been uncompetitive, there has been more competition and representative alternation both on the leadership board as well as the board of trustees. Furthermore, annual re-elections are also held in the branch and district organisations.

Members can raise issues through a hierarchical process by bringing the issue from the local branch level to the district level leadership, which plays a critical role in moving these issues onto the agenda of the board of trustees, from where input is given to the leadership board. While this mechanism was underlined in several interviews, there is no automatic guarantee that every issue raised reaches to the party leadership: It all depends on the nature of the proposal, context, etc. The district level organisations also legitimise the national level political process, as the MPs elected from the district frequent the district organisation meetings and bring news from the legislative arena.

EKRE has also developed participatory instruments for allowing grassroots level initiatives within the party. For instance, $1 / 10$ of the party members can initiate party charter amendments provided that they represent more than one district. The district assemblies and board of trustees are obliged to discuss the proposal before it is voted on by the party congress (2/3 support is required for acceptance).

The branch and district level organisations also have notable control over the candidate selection process. The local election candidate lists are drawn up by the branch organisations and districts decide most of the candidates for their electoral district in the general election. The leadership board can amend lists by only $1 / 5$ 
before the party congress approves the list of candidates. However, for almost all elections, there has been at least one fallout between the local and central leaderships over top positions in electoral lists. For instance, when the central leadership tried to replace the top candidate for elections in Tartu city, it resulted in a prolonged conflict within the local party branch, re-election of the local branch chairman, and forcing the former chairman to leave the party (Saar, 2020). Thus, critics have seen the candidate selection procedure and frequent intra-party elections as an instrument that helps leaders keep unruly local elites in check.

Electoral manifestos are compiled by a special committee summoned before every election for drafting the party manifesto. All party members are free to send their proposals and ideas to the committee. Our interviews indicate that the committee is a relatively autonomous body, and although the party leadership can later make some amendments to the draft manifesto, this right is not excessively used. The manifesto is later approved by the party congress.

However, there are also several non-institutionalised arenas through which members and even supporters have been able to influence the intra-party decisionmaking processes. For instance, one of the interviewees described that when Mart Helme served as minister of the interior and got involved in a serious political scandal, the chairman of the party, Martin Helme turned to the selected members of the leadership board and board of trustees to discuss the situation and political strategies. Other interviewees have also mentioned instances where the Helmes have changed political tack due to internal discussions in the party regarding the appointments of government ministers or select policy positions. For instance, regarding forestry policy, EKRE initially supported a more pro-industry policy, but when a notable number of members yearned for a more environmentalist position, the party agenda also shifted. However, it is important to point out that such conflicts have not had an impact on the core issues of the party.

The party leadership is also rather receptive to the members' and sympathisers' feedback online, i.e., through the EKRE's Friends Club Facebook group as well as via personal accounts. For instance, in 2018, the well-known singer Siiri Sisask was about to join the party ranks and run as a candidate on the invitation of the party leadership. When she revealed that she personally held rather liberal views on same-sex couples, the discussions on EKRE's Friends Club Facebook discussion board grew ballistic. Eventually, the leadership, which was willing to ignore this fact, revised their position, and Sisask renounced her candidacy.

Occasionally ordinary party members have had a chance to express their opinion even with regard to more strategic matters. One of our interviewees described:

Since EKRE became a government party, the regular online surveys started to appear in the [elec- tronic] mailing list of party members. As far as I know, the feedback collected was often taken into account while making decisions in the government. (Interview 12)

Thus, EKRE features both institutionalised and functioning intra-party democracy arenas as well as noninstitutionalised channels through which they keep their supporters engaged. While in principle these channels can also be used for other purposes-e.g., the frequent elections can also be used for grooming new dynamic elite for the party as well as co-opting dissenting local elites-it is still fair to say that EKRE's internal engagement mechanisms are fairly well-developed in comparison with some other Estonian parties (see Aylott, 2014). As one of our interviewees from the leadership board explained the evolution of power concentration in EKRE: "It is inevitable that the party's public face is their leaders....When the party was founded, the leader was playing a prominent role in decision making, indeed, but nowadays there are more extensive and inclusive discussions within the party" (Interview 10).

When comparing the centralisation of power and intra-party democracy in EKRE with its predecessor (ERL), one can find notable path-dependency: Both are fairly leader-centred parties with a leaning towards the diffused leadership model (Jakobson et al., 2020; Saarts, 2015). However, ERL provided fewer arenas for an active engagement for its members: There were less frequent intra-party elections, fewer active affiliated organisations, and the internet engagement platforms were relatively underdeveloped, resulting in a less vibrant intra-party democracy. Yet, as with the mass party type structure in general, the responsiveness of the elites and the frequent elections can be associated with the party's age, the need to maintain a dynamic activist core, and upholding the party's public image.

\section{Conclusion}

The study demonstrates that EKRE evokes all the features of a mass party type organisation: It has a relatively large membership-based organisation that is rapidly expanding, a strong rootedness on the ground supported by an extensive network of local party branches and affiliated organisations, and the party has a solid core of devoted activists who rely on a coherent and wellarticulated ideology for constructing their distinctive collective identity. Some of these features are inherited, which has made building up a mass party type organisation and legitimising EKRE as a major player notably easier than it might otherwise have been. Yet, in many respects, EKRE is an even more typical mass party than its predecessor, particularly due to its strong ideological core and the ability to inspire ideological devotion among its members. Thus, the case of EKRE conforms with Arter's (2012) observation that "successor parties" never become the replicas of their predecessors, but 
experience a substantial transformation and develop new qualities of their own.

EKRE has also developed an extensive online ecosystem for promoting its ideology and engaging its members, and has been more successful at it than any other party in contemporary Estonia. While the public image of the party is quite leader-centred, the mechanisms for members' engagement have become increasingly important-even to a larger extent than other electorally significant Estonian parties which tend to cultivate more managerialist styles. Therefore, when it comes to powercentralisation EKRE is not considerably more centralised than many other Estonian parties (see Aylott, 2014). However, evidence of internal democracy is still rather contradictory. While the leadership is re-elected annually and the vice-chairs change over time, the elections of party chairs tend to be uncontested. The same is evident at the local level: Frequent local level elections and candidate selection procedures are, on one hand, an indicator of internal democracy, but on the other hand can also be used to keep dissenting activists in check. Nevertheless, the open and participatory system has helped the party to build a vibrant and geographically extensive network of activists and local elites who are well-informed about the central level decision-making and have a channel for promoting issues relevant for them.

There is no doubt that EKRE was in an advantageous position in being able to take over the empty shell of its predecessor (ERL), which saved the party from having to build a mass party organisation from scratch. However, the party put great effort into further developing and expanding the party organisation and making it even more compatible with the mass party type. Thus, adopting the mass party structure is not just a sui generis move, but a deliberate strategy into which the organisation has invested.

In the previous sections, we highlighted three major reasons why EKRE adopted the mass party type of organisation: (a) an aspiration to gain wider societal and political legitimacy as a true "people's party" (the "populist argument"), (b) the socio-demographic profile of their electorate (the voters belonging to the lower classes and older generations living predominately outside of big cities), and (c) competition with other parties which had already developed extensive membership-based party organisations. While the first reason could be derived from PRRP ideology (at least to some extent), the second is mainly based on pragmatic considerations; the third reason purely relates to the local political context. In Estonia, where almost all the major parties have made a considerable effort to increase their membership and extend the geographical scope of their party organisations (see Tavits, 2013), any party with a serious ambition to become a significant actor in Estonian politics (and EKRE definitely has that ambition) had to act in a similar fashion. In short, the specific political circumstances and necessities largely favoured a more considerable organisation-building effort, and it should be noted that EKRE surpassed the other parties in developing a well-articulated ideology and devoted activist core.

Finally, the mass party type organisation is aligned with EKRE's ambition to be "the most ideological party" in Estonia. Such a goal is also facilitated by growing societal demand in Estonia for a party espousing a nationalist and socially conservative ideology. Hence, not only the ideological devotion of its members, but also the fact that EKRE is directly or indirectly supported by a wider national-conservative social movement made it easier for the party to expand and engage with potential supporters - in short, to adopt the mass party model.

In conclusion, EKRE serves as a good example of a relatively new PRRP with a mass party structure, that also puts considerable effort into party institutionalisation and nurturing new party elites. It facilitates frequent internal elections which attest to a significant degree of internal democracy for a PRRP. Interestingly, the case of EKRE demonstrates that charismatic leadership should not be seen as an indicator of an under-institutionalised and personalistic power vehicle. Rather, charismatic leadership and even some hereditary features can coexist with an articulate mass party structure. EKRE, like many other PRRPs, has a clear preference for hierarchy over deliberation, but they have institutionalised a system where frequent elections facilitate moderate diversification of party elites and encourage the engagement of local ones.

\section{Acknowledgments}

First and foremost, we are grateful to our interviewees who allowed us to get a deeper glimpse into the EKRE's party organization and its institutional practices. We are also thankful to the anonymous reviewers who made very constructive suggestions and the editors of the current thematic issue, Stijn van Kessel and Daniele Albertazzi, who provided very useful feedback and made many insightful comments on the various drafts of this article. This research has been supported by the European Union's Horizon 2020 research and innovation program under Grant Agreement No. 857366.

\section{Conflict of Interests}

The authors declare no conflict of interests.

\section{Supplementary Material}

Supplementary material for this article is available online in the format provided by the author (unedited).

\section{References}

Albertazzi, D. (2016). Going, going,... not quite gone yet? Bossi's Lega and the survival of the mass party. Contemporary Italian Politics, 8(2), 115-130.

Albertazzi, D., \& van Kessel, S. (2021). Right-wing populist 
party organisation across Europe: The survival of the mass-party? Introduction to the thematic issue. Politics and Governance, 9(4), 224-227.

Arter, D. (2012). Analysing 'successor parties': The case of the True Finns. West European Politics, 35(4), 803-825.

Auers, D., \& Kasekamp, A. (2013). Comparing radicalright populism in Estonia and Latvia. In R. Wodak, M. KhosraviNik, \& B. Mral (Eds.), Right-wing populism in Europe. Politics and discourse (pp. 235-248). Bloomsbury Academic.

Auers, D., \& Kasekamp, A. (2015). The impact of radical right parties in the Baltic states. In M. Minkenberg (Ed.), Transforming the transformation? The East European radical right in the political process (pp. 137-153). Routledge.

Aylott, N. (2014). A question of priorities: Candidate selection in Estonian political parties. Journal of Baltic Studies, 45(3), 321-344.

Biezen, I. v., Mair, P., \& Poguntke, T. (2012). Going, going,... gone? The decline of party membership in contemporary Europe. European Journal of Political Research, 51(1), 24-56.

Braghiroli, S., \& Petsinis, V. (2019). Between partysystems and identity-politics: The populist and radical right in Estonia and Latvia. European Politics and Society, 20(4), 431-449.

Eatwell, R. (2018). Charisma and the radical right. In J. Rydgren (Ed.), The Oxford handbook of the radical right (pp. 251-268). Oxford University Press.

Espenberg, U. (2018). Oma meedia rajamine oli ainuõige otsus [The decision to establish our own media outlets was the right one]. EKRE. https://ekre.ee/urmasespenberg-ekre-kongressil-oma-meedia-rajamineoli-ainuoige-otsus

Estonian e-Business Register. (2021). Political parties membership lists. https://ariregister.rik.ee/index? lang=eng

Estonian minister under fire after mocking Finnish PM as 'sales girl.' (2019, December 17). The Guardian. https://www.theguardian.com/world/2019/dec/17/ estonia-minister-who-mocked-finland-pm-survivesconfidence-vote-sanna-marin-mart-helme

Estonian National Electoral Committee. (2021). Valimised [Elections in Estonia]. https://www.valimised. ee/en

Gemius. (2021). Delfi audience overview by unique browsers. https://rating.gemius.com/ee/overview

Heinisch, R., \& Mazzoleni, O. (Eds.). (2016). Understanding populist party organisation. The radical right in Western Europe. Palgrave Macmillan.

Helme, M. (2020, July 4). Martin Helme: Ma tahan, et Eesti oleks nagu Läänemere Šveits [Martin Helme: I want Estonia to be like Switzerland in the Baltic Sea] [Speech transcript]. ERR Uudised. https://www.err. ee/1109358/martin-helme-ma-tahan-et-eesti-oleksnagu-laanemere-sveits

Jakobson, M.-L., \& Kalev, L. (2020). COVID-19 crisis and labor migration policy: A perspective from Estonia. Frontiers in Political Science, 2. https://doi.org/ 10.3389/fpos.2020.595407

Jakobson, M.-L., Saarts, T., \& Kalev, L. (2020). Radical right across borders? The case of EKRE's Finnish branch. In T. Kernalegenn \& É. van Haute (Eds.), Political parties abroad. A new arena for citizenship? (pp. 21-38). Routledge.

Kasekamp, A., Madisson, M.-L., \& Wierenga, L. (2019). Discursive opportunities for the Estonian populist radical right in a digital society. Problems of PostCommunism, 66(1), 47-58.

Korhonen, K. (2020). Politics of fire: The commemorative torch rally 612 of the Finnish radical right. European Politics and Society, 21(3), 307-322.

Kund, O. (2012, February 20). Koitla: Me ei hakka IRLiga konkureerima [Koitla: We will not compete with the IRL]. Postimees. https://www.postimees.ee/745696/ koitla-me-ei-hakka-irliga-konkureerima

Kuusik accused of episode of physical abuse. (2019, July 7). The Baltic Times. https://www.baltictimes. com/kuusik_accused_of_episode_of_physical_abuse

Metrix Station. (2021). Statistics. https://metrix.station. ee

Mölder, M. (2020). Estonia: Political developments and data in 2019. European Journal of Political Research Political Data Yearbook, 59(1), 119-129.

Mudde, C. (2016). The populist radical right: A reader. Routledge.

O’Grady, S. (2020, November 9). Estonian cabinet minister to resign after calling Biden corrupt, saying Trump would emerge as election winner. The Washington Post. https://washintonpost.com/world/2020/ 11/09/estonia-trump-election-mart-helme

Panebianco, A. (1988). Political parties: Organization and power. Cambridge University Press.

Party Charter of EKRE. (2012). EKRE põhikiri [Party charter of EKRE].

Party Charter of EKRE. (2016). EKRE põhikiri [Party charter of EKRE]. https://www.ekre.ee/pohikiri

Petsinis, V. (2019). Identity politics and right-wing populism in Estonia: The case of EKRE. Nationalism and Ethnic Politics, 25(2), 211-230.

Saar, J. (2020, September 2). EKREst välja heidetud linnavolinik: Mart Helme vihkab Tartut [The city councillor expelled from EKRE: Mart Helme hates Tartu]. Tartu Postimees. https://tartu.postimees.ee/ 7052406/ekrest-valja-heidetud-linnavolinik-marthelme-vihkab-tartut

Saarts, T. (2015). Persistence and decline of political parties: The case of Estonia. East European Politics, 31(2), 208-228.

Stier, S., Kirkizh, N., Froio, C., \& Schroeder, R. (2020). Populist attitudes and selective exposure to online news: A cross-country analysis combining web tracking and surveys. The International Journal of Press/Politics, 25(3), 426-446.

Tavits, M. (2013). Post-communist democracies and party 
organization. Cambridge University Press.

Toomla, R. (2011). Eesti erakonnad 2000-2010 [Estonian parties 2000-2010]. Tartu Ülikooli Kirjastus.

Trumm, S. (2018). The 'new' wave of populist right-wing parties in Central and Eastern Europe: Explaining electoral support for the Conservative People's Party of Estonia. Representation, 54(4), 331-347.

Wierenga, L. (2019). Bauska's chairmen: Party leadership and Twitter engagement in Estonian and Latvian populist far-right parties. Polish Political Science Review, 7(1), 138-154.

\section{About the Authors}
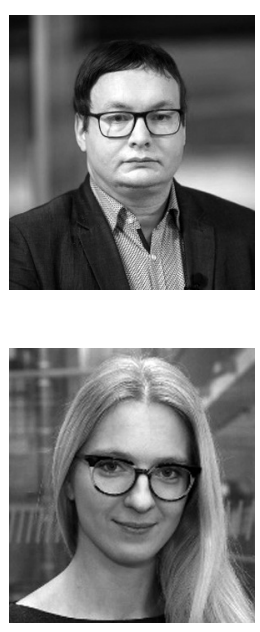

Mari-Liis Jakobson is an associate professor of political sociology at Tallinn University. Her research focuses primarily on migrant political transnationalism, populism, and transnational political parties. Her more recent publications include chapters in edited volumes published by Springer, Palgrave, and Routledge, and journal articles in Europe-Asia Studies, Comparative Migration Studies, and Frontiers in Political Science.

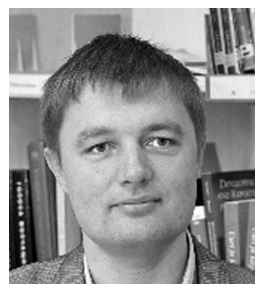

Leif Kalev is a professor of state and citizenship theory at Tallinn University. His research interests include citizenship, the state as a political community and its modes of governance, democracy, globalisation, transnationalisation, and political parties. His more recent publications include an edited special issue in Acta Politica Estica and articles in the International Journal of Public Policy, Social Science, and Comparative Migration Studies. He has also published with Springer, Peter Lang, and Routledge. 